POLITICAL CONTESTATION: POLITICAL ELITE CONTESTATION OF BALANIPA KINGDOM AND NETHERLAND COLONIAL GOVERNMENT IN 1870-1905

\title{
ABD. KARIM
}

Postgraduate of Historical Science, University of Indonesia

\begin{abstract}
The war of interests between the political elite and the others have a purpose of power. This phenomenon also happened in Balanipa Kingdom. The Balanipa is the greatest kingdom in Mandar, West Sulawesi Province, Indonesia.

It was started from the day when Netherland came to Mandar in order to colonialize the Kingdom. At the time, Netherland involved themselves in the system of Balanipa's Kingdom government. Finally, Netherland succeeded to bring the Kingdom's political elite into a conflict which was the Kingdom's political elite itself also have their own interests. Netherland succeeds to divide and conquer the Balanipa's government. The King of Balanipa even called as a traitor. Therefore, the political contestation happened as Netherland planed and it tended to bring favorable to Netherland. As a result, the kingdom of Balanipa was dominated by Netherland. In fact, this political contestation brought the serious impacts; today the Kingdom of Balanipa was forgotten by the society.

Based on the reasons, this research will reveal the contestation of Balanipa Kingdom political elite in 1870-1905. In addition, this research will reveal how political elites struggled in the Balanipa Kingdom, and how Netherland's government involved themselves as a major actor in the conflict of political elites. To analyze the political contestation, the researcher will use the theory of power from Michel Foucault. Meanwhile, the researcher will apply the method of historical research, including heuristics, critique, interpretation, and historiography.

The researcher expects that the results of this research will be used as references for the next researchers. Moreover, the researcher hopes that the research can be the references in the development of Balanipa future as well as establishing identity, open the lost greatness memory, and strengthen the local wisdom in Mandar.

KEYWORDS: Balanipa, Mandar, Political Contestation \& Political Elite Traitor
\end{abstract}

Received: May 31, 2017; Accepted: Jun 20, 2017; Published: Apr 17, 2018; Paper Id.: IJPSLIRAPR20181

\section{INTRODUCTION}

BACKGROUND

Mandar that the ethnic group from Sulawesi, one of the bigger tribe in South Sulawesi. Although the Bugis is the bigger and very famous in South Sulawesi, Mandar is the Bigger ethnic group in West Sulawesi either. Definitely, Mandar and Bugis have the difference, mainly the culture and the language. But they have much equations, one of them is the myth. tomanurung ${ }^{l}$ is the great myth from Sulawesi that story written by an ancestor in the past. Even though the story is

\footnotetext{
${ }^{1}$ The author is awardee of Lembaga Dana Pendidikan, This research is supported by Lembaga Pengelola Dana Pendidikan (LPDP)

${ }^{1}$ Tomanurung is the man come to the society for resolve the chaos that no one know where he come from. And finally become leader in that area afterwards
} 
the myth but it can make the historian realize the even in the past. Like Barthes said, myth is the system ${ }^{2}$. It is able to guide historian towards to event moreover the fact. In this case, the writer will exercise the myth for taking the fact in the past. Basically to reveal a history of Balanipa's Kingdom in Mandar.

Balanipa is the greatest kingdom in Mandar, to be "father" on seven kingdoms that fused in the federation is called Pitu Ba'bana Binanga (seven kingdoms in coast). The Kingdom of Balanipa was builtby I Manyambungi that he called Todilaling. The rise of Balanipa come about a seventen century during the reign of the second king that called Tomepayung(leyds, 1940: 26, Lotarak Pattodioloang, 1991: 41, Mandar script, : 109 dan Naskah Awal Sejarah Mandar, 2010 :58). He is a child of I Manyambungi. At the time, Balanipa has a good government, a good political structure, and economic structure. The king was selected from the family of noble. A reasonable condition in feudal period. On the other hand, the candidate of the king has to fulfill any requirements which it representation of a good king.

Started from the Netherland come to Mandar and has a trading. Initially, Balanipa as "father" on federation accepted the trading because it can make the economy of Balanipa better than before. Not only that but also can make the people prosperous. However, since the Bongayya agreement was signed by Sultan Hasanuddin -the king of Makassar Kingdom- it slowly changes. The Netherland started acting repressive and finally build the power in Mandar to dominate that territory for the Netherland interest.

In this case, this paper will examine how the Netherland take the Balanipa Kingdom in 1980-1905, what happen in that period is the general question but the writer will try to review on political side, how the Netherland power influence the goverment system of Balanipa Kingdom, including the elite politic contestation until how the Netherland Government change the system which it has become culture in the Balanipa Kingdom, particularly the selection of leader. For that question, the writer perceives contracts between Mandar and Netherland through the archive and Lontarak ${ }^{4}$.

\section{METHODS}

Power is not a unidirectional relationship subjectively. power is not a privilege that is earned or retained the dominant class, but as a result of the overall strategic position. a result that shows their position dominated (Michel Foucault, Surveiler et Punir., hlm 35$)^{5}$. by using the method of historical research, including heuristics, critique, interpretation and historiography. I will combine that Foucault's concept and the Historical Method to find the contestation in Mandar. That Foucault says "the power is the result of the overall strategic position" and I Believe, Behind the contestation, there is always a power that makes someone has desire to become king, absoulutely in this case.

\section{Mara'dia ${ }^{6}$ PERIOD}

It is too important that we know about the government system of Balanipa. started from Mara'dia period, the government system of Balanipa was started by the first king of Balanipa I Manyambungi, the man who becomes a heroin

\footnotetext{
${ }^{2}$ Roland Barthes, Mythologies, (New York : Hill and Wang 1983), page 151

${ }^{3}$ Is the federation that Balanipa become leader among the seven kingdom namely Sendana Kingdom, Banggae Kingdom, Pamboang Kingdom, Mamuju Kingdom, and Tappalang Kingdom

${ }^{4}$ Lontarak is the ancient manuscript from Sulawesi that wrote on lontarak leaf, which used local language tribes and used local script. Although the culture is different but they are use the similar script.

${ }^{5}$ On Haryatmoko, Membongkar Rezim Kepastian Pemikiran Kritis Post-Strukturalis, (Yogyakarta : PT. Kanisius, 2016) page 15 .

${ }^{6}$ Mara'dia is the title of King in Mandar
} 
Balanipa. where he conquers the Passokkorang Kingdom ${ }^{7}$ before. In other words, Mara'dia Period begin after Passokkorang Kingdom is defeated by I Manyambungi. Even though I Manyambungi has defeated the Passokkorang but the Balanipa Kingdom become the greatest Kingdom in Mandar in Tomepayung era. He success make the good government structure in all fields.

The structure is, Mara'dia as a king, Appe' Banиa Kaiyyang (four big country) as prime minister that establish the policy, Mara'dia Matoa as royal advisors, Mara'dia Malolo as ministry of defence, two Pa'bicara, eight Pappuangan as the cabinet minister it called Ada' Sappulo Sokko' and syahbandar as the man who oversee the trade in Mandar. ${ }^{8}$ That system is regenerated by Tomepayung for the kingdom interest. But there is something interesting when Mara'dia on the control Appe' Вапиа Kaiyyang, as we know the bigger power on kingdom is the King, but in this case, the has a legitimation on the kingdom but not all. Moreover, the king has to ask to Appe' Banua Kaiyyang for deciding the policy.

It is indicated that the prime minister has a more legality than the king. That is mean real hierarchy in Mandar not fully implemented. Legality in question is if the prime minister deciding to terminate the king occupation but under certain condition. Written in lontarak, that condition is the sea no longer produce something, field and farm also, no more honest people, long drought and the famine are coming ${ }^{9}$. As has been said before, myth is the system it have to interpretate, as the text of lontarak need also. The text above, that means the king must make the people welfare on all sides, on the sea or on the ground. Moreover, the king must prepared to sense what people sense. Apart from it, the role of king on government too important, that not mean the king just become "shadow" on the structure.

An another side, the Mara'dia period exhibit to us that the real power comes from the people not only prime minister or the king. Although the policy is decide with the king and prime minister but they are useless on the structure moreover they are to be fired if they are irresponsible. So far it is the democracy which we know today, that we use on national political. Mainly in Indonesia. Actually, local wisdom not only tell about the people habit on art or something make people impressed because see the "ritual" but also on political culture on local wisdom necessary notice.

Local politics is very interesting because it could reveal the identity of a group or a community by using a memory that inherited the historian can imagine the event in the past. Collective memory is a form that is referred to, where the person does not behave well aware of what is done is sourced from the past. Moreover, as a way to pass the memory is well done, furthermore Mara'dia government system will be inherited from generation to the generation ago.

This legacy is still felt to this day, wherein each of the local elections, mara'dia title name is always used in the campaigns, an indication that the greatness of the kingdom's legacy remains today, although suffered several attacks from several sides even in its development, mara'dia always be a position in the desire by the descendants of nobles in Mandar. Moreover, in the kingdom, as mentioned earlier.

Several events took place in Mandar because of the power struggle. Including when the Netherland began to enter Mandar which the Netherlands also intends to take control of Makassar and Mandar after the Makassar war in 1667 and

\footnotetext{
${ }^{7}$ Transliterasi dan Terjemahan Lontara Mandar ( Naskah Mandar ). ( Majene : Disporabudpar Kabupaten Majene Bidang Kebudayaan Seksi Nilai-Nilai Tradisional Sejarah Permuseuman Dan Kepurbakalaan, 2010), page. 108.

${ }^{8}$ Madjid Tanawali Azis Syah. Pola Kepemimpinan Tradisional di Mandar. Dalam laporan Hasil Seminar Kebudayaan Mandar I Tanggal 31 Juli S/D. 2 Agustus 1984 di Majene, page. 191.

${ }^{9}$ Ibid.,page. 17-18. Lihat pula dalam A. M. Mandra dkk. Mandar dalam Lontar Mandar. (1990),page.116.
} 
Bongayya agreement is signed $^{10}$. An agreement between the kingdom of Makassar by the Netherland colonial government in which the fate of entire kingdoms previously worked with Gowa fall into the hands of the Netherlands. Except for Mandar that they do not want to submit the agreement and do not obey Netherland. Finally on October 101674 "Banggai tractaat"11 is Signed. which is a cooperation agreement between the Mandar and the Netherland colonial government. Mandar represented by Mara'dia Tomatindo di Langgana and on the Netherland was represented by the Resident Harthoufer ${ }^{12}$, The political strategy is the one used by the Netherlands in this period, by way of consultation with Mandar that it represented by Balanipa, Netherland can control Mandar slowly.

\section{A POWER STRUGGLE IN MANDAR}

Temporal limits were examined in this study starts from 1870-1905, the reason the author chose the time limit for the fight between the three great powers are very noticeable. Three great powers in question are the three forces of the ruling power of the first and second of the local nobility and the third force that the Netherland colonial government. which at that time wanted Mandar controlled sepenuhanya. Furthermore, the fight illustrates how conflicts that occur between local elites who also want power. Internal conflicts royal coloring the contestation, despite having the same blood, it does not loosen tensions in Mandar that time.

I Mandawari is the king of the 45th and was appointed in 1870, where he was known as the king indemnify the Netherlands as compensation for the robbery of Netherland ships passing through the waters of Mandar. for breach of the contract, in 1864 all over the kings of Mandar invited to Makassar to resolve this problem. But kings in Mandar do not heed the invitation. Netherlands then sent the Secretary v / d inlandse zaken vool to resolve the issue but the Kings did not like the attitude of the secretary and eventually expelled ${ }^{13}$. The situation gets worse and eventually, with Gubernemen decision dated May 19, 1866 No 26 gives the power to take tough action against kingdom breach previously agreed a contract $^{14}$. And the culmination of this conflict is when Banggae King's Palace was burned by the Netherland in $1867^{15}$.

\footnotetext{
${ }^{10}$ M.T. Azis Syah. Lontarak 1 Pattodioloang di Mandar. ( Ujung Pandang : yayasan dan kebudayaan "TARUNA REMAJA", 1992 ), page. 74

${ }^{11}$ Banggai Mandar Tractact constitute an agreement between the Netherlands on 10 October 1674, that called BanggaiTractact because the agreement made in BanggaiMajene. This agreement is motivated conflict between the Netherland-Mandar during which a war Mandar-Netherland. Mandar people's struggle against the Netherland and the signing of the agreement ending the Banggai The contents of this agreement as a continuation of the treaty of bongayya on 18 October 1667, Here are the contents of Banggai Treaty on record W.J. Leeds. "In the contract stipulated: that would be paid some compensation, friend of the Company was her friend, enemy of the Company are also enemies when called should be to Makassar, breakout-breakout should be arrested and confronted if it is out of the country must be fitted in Makassar, may not navigate the river -sungai in Sulawesi without isin of resident all trades to be done by the Company and the Company have the freedom to sail the rivers of Mandar and established forts and so forth; Binanga-Karaeng environment (the name of the river which is the border between Binuang and ajatappareng), Kadokang and.... (illegible) must be returned to Sawitto; 30 slaves should be given to the Company as compensation for the cost of war ". content of the agreement can be reviewed over time that Mandar was truly lost to the Netherlands seen from the contents of any agreement in favor of the no Mandar. As for the reason why the Banggai serve as the signing of agreements for Banggai position is strategically very suitable as a center of government for Balanipa area while it is still dangerous for the Netherlands. means the Kingdom Balanipa and society is at that time could not accept the Netherlands

${ }^{12}$ Syaiful Sinrang. Mengenal Mandar Sekilas Lintas Perjuangan Rakyat Mandar Melawan Belanda 1667-1949. (Ujung Pandang : Yayasan Kebudayaan Mandar Rewata Rio, 1994 ), page. 112.

${ }^{13}$ Translation from : NOTA Van Toelichting Betrefende Het Landschap Balangnipa, Tjjd. Liv 503-535.192, op. cit., page. 22. ; Syaiful Sinrang, op. cit., page. 131

${ }^{14}$ Ibid, page 22

${ }^{15}$ Syaiful Sinrang. Mengenal Mandar Sekilas Lintas Perjuangan Rakyat Mandar Melawan Belanda 1667-1949. (Ujung

Pandang : Yayasan Kebudayaan Mandar Rewata Rio, 1994 ), page. 142
} 
Problems then arise in 1870 because I Mandawari as king Balanipa renew the contract with the Netherland side where he agreed to indemnify an event that occurred in the previous year. In the records of the Netherlands that stated,

Next result for a while in 1870, Maradia Malolo of Majene named Manawari chosen to be king, and with had at go to Makassar.

Of compensation demanded as much f3.500.- paid in installments made by the king. Before that preceded the inauguration with a new contract from the New King Manawari As Balanipa ${ }^{16}$

This decision is quite detrimental at that time, because the kingdom should be compensated for what happened earlier, on the other hand Mandar, must transform itself as a result of attacks by the Netherland to burn the royal palace Banggae. Mandawari as King Balanipa and represent Mandar approve the agreement. A result of this decision, Mandawari under fire from the court that the decision was very detrimental it gives birth to an internal conflict that continues to grow, the conflict between the indigenous people who do not want the Mandar cooperation with the Netherlands and the parties that support the decision Mandawari. do not agree clearly illustrated that they do not want to cooperate with the Netherlands and the side have agreed to cooperate with the Netherland could have been thinking diplomatically, that this is a political strategy that will be run so that the existence of the Kingdom Balanipa maintained properly. Regardless of the success or failure of the strategy, the agitation going on between the two sides and the conflict is prolonged.

\section{REBELLION TOKAPE}

As the side do not agree with the decisions I Mandawari, Tokape who is a cousin of the I Mandawari ${ }^{17}$, take the fight to the Netherland and opposed the agreement made by Mandawari and the Netherlands. The resistance is indicating that the kingdom's internal conflict has occurred. moreover, this opposition was supported by the Hadat kingdom. This conflict is growing and peaked in 1872. Tokape as the group fully supported by the Hadat, managed to seize the throne of power from I Mandawari. Mandar-Netherland relations strained back. It is caused by a king who replaced Mandawari did not want to cooperate with the Netherlands and one of the causes Mandawari successfully stepped down from his post because of the support of the Hadat to Tokape, that the Hadat also do not want to cooperate with the Netherlands. Mandawari defeat in the power struggle, he was forcibly removed to make Pamboang as mentioned in lontarak that,

Mara'dia Kecce surrounded Because of some people Balanipa an opponent.

Tomelloli 'retreated to Pamboang with drums, then from Pamboang beliu continue to Ujung Pandang, after he was in Ujung Pandang. Appe Banua Kaiyyang to Pamboang to take the drum. ${ }^{18}$

Furthermore, Mandawari who lost went to Ujung Pandang (Makassar). In the source does not explicitly described Mandawari goal that went to Makassar, but if studied further, that attitude shows that Mandawari needs protection from the Netherlands, where he had been rejected by the had at own kingdom and its people. After the victory over Mandawari

\footnotetext{
${ }^{16}$ Translation from : NOTA Van Toelichting Betrefende Het Landschap Balangnipa, Tjjd. Liv 503-535.192, op. cit., page. 22.

${ }^{17}$ M.T. Azis Syah. Lontarak Pattodioloang 1 dan 2 di Mandar 2. ( Ujung Pandang : yayasan dan kebudayaan "TARUNA REMAJA", 1992 ), page. 100.

${ }^{18}$ M.T. Azis Syah. Lontarak 1 Pattodioloang di Mandar 2. ( Ujung Pandang : yayasan dan kebudayaan "TARUNA REMAJA", 1992 ), page. 100.
} 
Tokape, Balanipa royal throne in the hands of Tokape as king of the 46th. In lontarak Tokape mentioned that during the rule of the people safe and secure. It is following excerpt lontarak manuscripts,

At the time Tokape is Mara'dia in Balanipa, directly into a secure kingdom. Although the door is not closed Balanipa no theft. The Hadat said: "tomorrow or the day after there were burgled then caught, kill the thief. Thus already Balanipa safe ${ }^{19}$.

Lontarak describing the condition Balanipa after a conflict between the I Mandawari and this indicates that the presence Tokape, I Mandawari as a figure of the king brought unrest in the society, moreover, his attitude that impressed the pros against the Netherlands.

On the other hand, Mandawari who went to Makassar to ask for the protection of the Netherland support and ended during the reign Tokape, several times the Netherland military expedition, even the Governor of Celebes J. L. Couvreur say that the resistance led by Tokepe this is the greatest resistance to the 5th of Mandar people against the Netherland colonial government ${ }^{20}$. But in the end, the Netherlands can reduce the resistance, arrested and banished to Pacitan Tokape Madiun in 1873 and he was replaced by Mandawari as King Balanipa ${ }^{21}$

\section{MANDAWARI VICTORY IN THE NETHERLAND SIDE}

Tokape captured and the decision of the Netherland colonial government Mandawari re-elected as King Balanipa 47th. As written in lontarak that,

After Tokape lost cousins back replace only time, at the discretion of the Netherlands named Imannawari.

Ammana Icalla 're so Mara'dia Balanipa by the Netherland decision.

Ammana Icalla 're so Mara'dia Balanipa the will Gubernamen.

Upon returning dariUjung Pandang I Puwang Bakkarang he brought the contract and submit it to Mara'dia Kecce to implement the government in Balanipa. ${ }^{22}$

Political relationships I built with Netherland Mandawari bring a significant impact on developments kingdom Mandar perlahansudah Balanipa especially in the grip of the Netherland colonial government.

The most important of the political relations between the Mandar-Holland is the stability of security in Mandar despite being under Netherland control internal conflicts which previously heats eventually disappear by itself regardless arrest Tokape as the man who became a leader in the Mandar people's resistance against the Netherland colonial government on the other hand, people who then have to obey the kingdom and Netherland colonial government would not want to follow all their policies.

\footnotetext{
${ }^{19}$ M.T. Azis Syah. Lontarak 1 Pattodioloang di Mandar 2. ( Ujung Pandang : yayasan dan kebudayaan "TARUNA REMAJA”, 1992 ), page. 101.

${ }^{20}$ Syaiful sinrang, op. cit., page 156; Idham dan saprillah, sejarah perjuangan pembentukan provinsi Sulawesi Barat, (surakarta: Zada Hanifa, 2010), page. 150. ; Suardi Mappangara, op. cit., page. 336.

${ }^{21}$ Tulisan Belanda yang terbit tahun 1909 yang berjudul "Mededellingen Betreffende Eenige Mandharsche Landschapen" dalam Syaiful Sinrang, op. cit., page. 154-155. ; lihat juga dalam Memorie W.J. Leyds Assisten Residen Van Mandar, (madjene: 9 Februari 1940), page. 36.

${ }^{22}$ M.T. Azis Syah. Lontarak 1 Pattodioloang di Mandar 2. ( Ujung Pandang : yayasan dan kebudayaan "TARUNA REMAJA”, 1992 ), page. 102.
} 
Struggles that happened before is not only motivated the desire for power either of I Mandawari sides and Tokape sides, but the role of the Netherland side that succeeded in pitting both the political elite is also very crucial. Holland became highly lethal weapons and bullets Mandawari be very sharp in which a combination of both makes Tokape gather people who have the power to take the fight to its knees. Apart from diplomatic stance owned by Mandawari, he continued working together with the Netherland to regain his throne as King.

"the power is dazzling, people are willing to suffer for sake of power". Foucault's view of power when connected to Mandar conditions at the time, can be a reference that is happening in the kingdom kotestasi Balanipa caused by Powers, although both sides have a specific purpose, but something to be achieved when it is how one of them became kings who have legitimacy in society. As mentioned before that the Netherland roles cannot be separated from the constellation that has been built from scratch since the Netherland role as a third force in this conflict is crucial. Without the presence of the Netherlands where the Netherland also wanted power in Mandar, the constellation will only be up to dismissal Mandawari as king by the tribe Hadat.

The creation of the tense conditions in Mandar motivated by the attitude of the Netherlands and the contracts agreed by Mandar and the Netherlands in 1873-1880 Balanipa not experiencing significant growth, in other words, Mandawari not bring positive impact although Mandar achieve security and stability, but the welfare of the people is not reached copra bought very inexpensively by Netherland, This condition is exacerbated by the attitude I Mandawari that just suck opium in the palace. Political attitude of the foregoing, wherein Mandawari devises a political strategy has not become a strong assumption to maintain its position as the king who had a diplomatic attitude.

This condition is exacerbated by Mandawari who like to suck Opium and lazing in the Palace. However Hadat are aware of these conditions take tough measures by replacing the I Mandawari as King in the writings of the Netherlands stated that,

In 1880 king her torch is met Manawari; hij had de Hadat tegen zich gekregen, waar deze met een nieuw gekozen Maradia, en wel den uit Madjene verjaagden Sanggaria naar Makassae trok, waar men, inziende dat Manawari zich niet kon handhaven, Sanggaria als Maradia accepteerde.

In 1880 it still went wrong with Manawari; he had the Hadat got to him, where it attracted a newly elected Maradia, namely from the Madjene chased Sanggaria to Makassae, where, seeing that Manawari could not maintain itself, Sanggaria accepted as Maradia ${ }^{23}$

Had at role that has the strong legitimacy to determine who deserves to be the king made Mandawari cannot do anything when he was replaced by Sanggaria. Sanggaria chosen to be king by the Hadat seems the state was forced, in a sense, sanggaria initially had no intention to become king, but because of the encouragement of the Hadat and their desire to replace Mandawari, finally sanggaria appointed King replaces Mandawari.

During the reign of Sanggaria, no records or notes in lontarak even Netherland depicting Mandar conditions at that time. but the authors find information sacking Sanggaria as King further in lontarak narrated.

Once appointed Mara'dia Banggae palace and moved to Marica built-in Ipuang Rengge Avalanche Limboro and marries her nephew with Mara'dia Kecce 'named Idalauleng. Already it. Hadat he met his neighbor and he said: "if God

\footnotetext{
${ }^{23}$ Tulisan Belanda dalam Syaiful Sinrang, op. cit., page. 156.
} 
wills, he who will be Mara'dia. Because I'm not a position I aspire Mara'dia Avalanhce.

Avalanhce Limboro answered: "I just hope mara'dia patient" will be heard by Tomelloli sepupupu once. Tomelloli to Avalanhce Limboro said: "between the drums here Avalance, later paraded here over there!" Heard Tonaung anjoro. He answered: "that is not true will of my cousin who later accused me that the drum is in exchange with men". They strove and failed to come marry people the Balanipa

Grieving person Balanipa Tonaung Anjoro dethroned.... ${ }^{24}$

Mandawari strength in the dialectic illustrated in the above quotation that he skillfully began the debate with Sanggaria and ended with the victory of dialectic. Which causes Sanggaria down from his throne. People cause Balanipa disappointed with Sanggaria cornered by Mandawari. Disappointment is what makes the had at forced to lower and lift Mandawari Sanggaria be Mara'dia. But in the source illustrated that Sanggaria does not want it served again as a king, instead he wants to surrender his throne to I ladulauleng. The news was heard by Mandawari and he was quick to respond to these conditions and managed to win a negotiation process that he proposed. Strength is owned by I Mandawari, she had skills in diplomacy. Apart from his ambition to be king.

Mandawari, the had at and the Netherlands contestation did not end there. After removal Mandawari as King Balanipa by the Netherland, the return of internal conflict in which both parties led by Ammana I Wewang. A figure of Mandar very ambitious to expel the Netherland colonial government in Mandar. On the other hand Mandawari as Mara'dia when it is wanted to cooperate with the Netherland colonial government. As for the reason Ammana Wewang resistance against Netherland colonial rule is as follows:

- Copra traders very nervous, because they copra purchased at very cheap prices, until they stow carry their copra to Java or directly to Singapore. The merchants in tangkapi by the Netherlands, fired at his boat to sink.

- A highly sensitive issue of religion in society mandated that one hundred percent Moslem. They consider that the Netherland colonialists who do not embrace the religion of Islam are infidels, so they become very difficult to integrate.

- Mandar people heartache for maraqdia Iboroa alias Tokape arrested and exiled by the Netherland island of Java. ${ }^{25}$

1905-1907 resistance by Ammana I Wewang took place. Although only two years but this resistance carries a very significant impact on the development of armies struggle in Mandar that time. This resistance is also influenced contestation started in 1870 by I Mandawari as a major actor in the struggle for power in the kingdom Balanipa. I will not discuss these events deeper but will examine the role I Mandawari in these events. Starting from Mandawari inauguration as king for the third time and the reason Ammana I Wewang take the fight against the Netherland colonial government. Mandawari subsequently appointed to be king for the third time clearly affected the Netherland position in Mandar like that has happened before when Mandawari served as king.

Mandawari interests of the Netherlands when it utilized to the maximum by the Netherland. where the Netherland are in condition to overcome the resistance carried out by Ammana I Wewang. Relief Mandawari as a person who knows the power Ammana I Wewang then, The Netherlands managed to overcome these problems and catch Ammana I Wewang

\footnotetext{
${ }^{24}$ Azis Syah, op. cit., page 105.

${ }^{25}$ A.M.Mandra. Sejarah Perjuangan Kemerdekaan Bangsa di Mandar. (majene : pemerintah Kab. Majene. 2002 ), page 9.
} 
and banished him to Belitung. Related assistance provided by Mandawari, previously signed a contract between Mandawari as King Balanipa and The Netherland colonial government in 1905. where the contents of the agreement is subject to the Mandawari Netherland colonial government and does not engage the enemy state by foreign powers the Netherlands ${ }^{26}$.

But a year later I Mandawari resigned from his position as Mara'dia. Mandawari resignation also on the support of the Netherland colonial government because he is already very old. and at the end of his Mandawari given some money by the Netherlands ${ }^{27}$. it seems clear that the role of Mandawari in the rest of his life, is not needed anymore by the Netherland In addition to his influence faded in Mandar, the Netherlands have Ammana Wewang dampen resistance has gained full legitimacy over Mandar region. Through Mandawari which acts as an actor in the conflict that began in 1870-1905, The Netherlands managed to bring Mandar entry into his hand. It is also associated with the policy of the Governor General of the Netherland East Indies where the entire territory of the colony will be established within the government and in the entire archipelago in the hands of the Netherlands.

Power is the result of all the mechanisms of action of a person or group clearly illustrated in this case. Political contestation which took place in Mandar which in this case involves three great forces that each has a purpose. The mechanism is made up of various events that occur within a period of 35 years and carries a significant impact on Mandar conditions at that time. The strengths of each respective forming mechanism, Mandawari with the power of diplomacy and its proximity to some of the Hadat and the Netherland colonial government. constellation formed clearly defined, where Netherland utilizes internal conflict between the political elite and successfully establish mechanisms to exert influence his power to succeed fully in Mandar.

\section{REFERENCES}

\section{A. Archieves dan Lontarak}

1. Anonim, Laoran Hasil Seminar Kebudayaan Mandar I Tanggal 31 Juli S/D 2 Agustus 1984 di Majene

2. Arsip Nasional, Kontrak Balanipa, No 662

3. Arsip Nasional, bb.28 1756. Acte Van Renovatie den Vorstan Van Mandhar, Contract mit Mandhar Balanipa 30 Mei 1850

4. C Noote Boom. 1994/1995. Laporan Penelitan dan Nilai Tradisional Sulawesi Selatan Kerajaan Balanipa -Mandar. Ujung Pandang : Departemen Pendidikan Dan Kebudayaan Direktorat Jendral Kebudayaan Balai Kajian Sejarah Dan Nilai Tradisional Ujung Pandang

5. Hanoch, Luhukay dkk. 2006. Memori Asisten Residen W. J. Leyds Selama Bertugas di Mandar. Yayasan Kaitupa

6. Mandra. A. M. 2015. Transliterasi dan Terjemahan Lontara Balanipa Mandar. Makassar : Kretakupa.

7. Syah, Tanawali Aziz. 1992. Lontarak 1 Pattodioloang di Mandar. Ujung Pandang: Taruna Remaja.

8. 1992. Lontarak 2 Pattodioloang di Mandar. Ujung Pandang: Taruna Remaja.

9. Yasil, Suardi dkk. 2012. Naskah Awal Sejarah Polewali Mandar. Polewali Mandar: Dinas Perhubungan, Komunikasi dan Informatika Kabupaten Polewali Mandar.

\footnotetext{
${ }^{26}$ Arsip Nasional, Kontrak Balanipa no 662

${ }^{27}$ M.T. Azis Syah. Lontarak 2 Pattodioloang di Mandar. ( Ujung Pandang : yayasan dan kebudayaan "TARUNA REMAJA", 1992 ), page.113-114.
} 


\section{B. Books}

1. Ahmad dkk. 2007. Sejarah Mandar dan Sejarah Perjuangan Bangsa Di Kab. Majene. Dinas Pendidikan dan Kebudayaan Majene Binmudorabud Seksi Kebudayaan

2. Haryatmoko. 2016. Membongkar Rezim Kepastian Pemikiran Kritis Post-Strukturalis. Yogyakarta : PT. Kanisius.

3. Mandra A M. 2002. Sejarah Perjuangan Kemerdekaan Bangsa di Mandar. Majene: Pemerintah Daerah Kab. Majene

4. Munoz Paul Michel. Kerajaan-Kerajaan Awal Kepulauan Indonesia dan Semenanjung Malaysia. Yogyakarta : Mitra Abadi

5. Sinrang Syaiful. 1994. Mengenal Mandar Sekilas Lintas ”Perjuangan Rakyat Mandar Melawan Belanda (1667-1949). Ujung Pandang : Yayasan Kebudayaan Mandar Rewata Rio

6. Genyi, George Akwaya, Militarization of African Societies and Its Impact on Political Life, International Journal of History and Research (IJHR)

7. Mengenal Mandar Sekilas Lintas. Group “Tipalayo” Polemaju Mandar.

8. Roland Barthes, Mythologies, 1983. New York: Hill and Wang, diterjemahkan oleh Nurhadi. A. Sihabul Millah. Mitologi. 2015. Bantul:Kreasi Wacana

9. Syah, Tanawali Aziz. 1980/1981. I Calo Ammana I Wewang Topole di Balitung Pahlawan Daerah Mandar Sulawesi Selatan. Ujung Pandang: Pemda T. K. I. Prop. Sulsel.

10. 1997. Sejarah Mandar Polmas-Majene-Mamuju jilid I, yayasan”Al-Azis”. Ujung Pandang : yayasan "Al-Aziz" Ujung Pandang.

11. 1998. Sejarah Mandar Polmas-Majene-Mamuju jilid II, yayasan”Al-Azis”. Ujung Pandang : yayasan “Al-Aziz” Ujung Pandang.

12. 1998. Sejarah Mandar Polmas-Majene-Mamuju jilid III, yayasan”Al-Azis”. Ujung Pandang : yayasan “Al-Aziz” Ujung Pandang. 